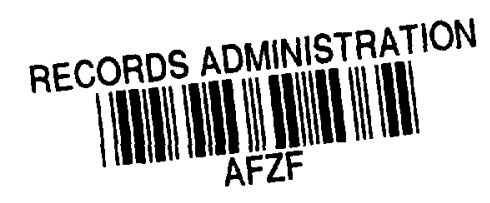

\title{
PREPARATION AND PROPERTIES OF \\ NITRATE-DEFICIENT GADOLINIUM NITRATE SOLUTIONS ${ }^{+}$
}

Elizabeth W. Baumann

Savannah River Laboratory, E. I. du Pont de Nemours \& Co., Aiken, SC 29801

Abstract - Gadolinium nitrate solutions ( $0.001 \mathrm{M})$ were made nitrate-deficient by contact with hydroxyl-form anion exchange resin. These metastable solutions aged with a decrease in pH and in the amount of soluble gadolinium. Gamma irradiation with ${ }^{60} \mathrm{Co}$ increased the rate of aging. Nitrate deficiency was qualitatively detected and quantitatively determined. At $\sim 23^{\circ} \mathrm{C}$, the solubility product constant, $\mathrm{K}_{\mathrm{sp}}$. of gadolinium hydroxide in an aged and irradiated solution in $\mathrm{H}_{2} \mathrm{O}$ was $10^{-26.8}$; for an aged solution in $\mathrm{D}_{2} \mathrm{O}, \mathrm{K}_{\mathrm{sp}}$ was $10^{-26 \cdot 6}$.

+ This work was presented in part at the 176 th National Meeting of the American Chemical Society, Miami Beach, Florida, September 1978; NUCL 037.

The information contained in this article was developed during the course of work under Contract No. DE-AC09-76SR00001 with the U.S. Department of Energy. 


\section{DISCLAIMER}

This report was prepared as an account of work sponsored by an agency of the United States Government. Neither the United States Government nor any agency thereof, nor any of their employees, makes any warranty, express or implied, or assumes any legal liability or responsibility for the accuracy, completeness, or usefulness of any information, apparatus, product or process disclosed, or represents that its use would not infringe privately owned rights. Reference herein to any specific commercial product, process or service by trade name, trademark, manufacturer, or otherwise does not necessarily constitute or imply its endorsement, recommendation, or favoring by the United States Government or any agency

thereof. The views and opinions of authors expressed herein do not necessarily state or reflect those of the United States Government or any agency thereof.

This report has been reproduced directly from the best available copy.

Available for sale to the public, in paper, from: U.S. Department of Commerce, National Technical Information Service, 5285 Port Royal Road, Springfield, VA 22161, phone: (800)

553-6847, fax: (703) 605-6900, email: orders@ntis.fedworld.gov online ordering: http://www.ntis.gov/ordering.htm

Available electronically at http://www.doe.gov/bridge

Available for a processing fee to U.S. Department of Energy and its contractors, in paper, from: U.S. Department of Energy, Office of Scientific and Technical Information, P.O. Box 62, Oak Ridge, TN 37831-0062, phone: (865 ) 576-8401, fax: (865) 576-5728, email: reports@ adonis.osti.gov 


\section{INTRODUCTION}

Because of the high neutron absorption cross sections of some gadolinium isotopes, gadolinium salts in solution are used to control nuclear reactivity in aqueous systems. At the Savannah River Plant, gadolinium nitrate at $0.001 \mathrm{M}$ in the reactor $\mathrm{D}_{2} \mathrm{O}$ coolant-moderator provides a supplementary mode of reactor shutdown [1].

The solution of gadolinium nitrate must be stable with respect to loss of dissolved gadolinium through precipitation or through deposition on reactor components. Gadolinium hydroxide can precipitate from metastable solutions that contain less than the stoichiometric amount of nitrate (nitrate-deficient solutions).

Hydrolysis of gadolinium salt solutions and the solubility of gadolinium hydroxide have been described [2]. However, reported work has been primarily concerned with solutions of the stoichiometric salts in $\mathrm{H}_{2} \mathrm{O}$. The present studies concern the preparation and analysis of nitrate-deficient solutions, the effect of time and gamma radiation on their stability, and the determination of the solubility of gadolinium hydroxide in $\mathrm{H}_{2} \mathrm{O}$ and $\mathrm{D}_{2} \mathrm{O}$.

\section{EXPERIMENTAL}

Preparation of nitrate-deficient solutions. $0.001 \mathrm{M}$ gadolinium nitrate solutions were prepared by dissolving $\mathrm{Gd}\left(\mathrm{NO}_{3}\right)_{3} \cdot 5 \mathrm{H}_{2} \mathrm{O}(\mathrm{Alfa}$ Products) in deionized water. Nitrate was selectively removed from the solution by contact with the anion exchange resin Amberlite $\left.{ }^{\circledR}\right] \mathrm{RA}-400\left(\mathrm{OH}^{-}\right)$(Rohm and Haas $\mathrm{Co}$ ), which was thoroughly 
washed with water before use. The nitrate-deficient solutions were prepared either by adding small amounts of resin to the solution (batch method) or by passing the solution through a column of the resin (column method).

Auxiliary procedures. Gadolinium was determined by titration with standard ethylenediaminetetracetic acid (EDTA), using xylenol orange indicator and hexamethylenetetramine hydrochloride buffer [3].

Nitrate was determined by ion chromatography [4], by nitrate-selective electrode using the standard addition/dilution technique [5]. or by ion exchange. In the ion exchange method, a known volume of solution was passed slowly through a column of the cation resin Amberlite ${ }^{\circledR}$ IR- $120\left(\mathrm{H}^{+}\right)$, and the column was subsequently thoroughly rinsed with water. The $\mathrm{H}^{+}$content of the combined effluent and washings, which represents the total nitrate content of the nitrate-deficient solution, was determined by titration with $\mathrm{NaOH}$.

"Soluble" and "insoluble" gadolinium species in the solution were separated by filtration through a Millipore ${ }^{\circledR}$ (Millipore Corporation) filter of 0.45 -micron pore size.

The $\mathrm{pH}$ and $\mathrm{pD}$ were determined in the conventional manner with a pH meter and a combination pH glass electrode. Commercial buffers in $\mathrm{H}_{2} \mathrm{O}$ were used to standardize the system for $\mathrm{pH}$ measurements. An acetate buffer of $\mathrm{pD} 5.23$ [6] and a phosphate buffer of pD 7.43 [7] were used to standardize the $\mathrm{D}_{2} \mathrm{O}$ system. 
Turbidity was measured nephelometrically with a Hach Laboratory Turbidimeter, Mode1 2100A (Hach Chemica1 Company), with liquid turbidity standards furnished with the instrument. Conductivity was measured at ambient temperature $\left(223^{\circ} \mathrm{C}\right)$ with an Electromark® Analyzer, Model 4403 (Markson Science, Inc.). Solutions were irradiated with a ${ }^{60} \mathrm{Co}$ source at a dose rate of $3.5 \times 10^{5} \mathrm{rad} /$ hour to a total dose of $7.0 \times 10^{6} \mathrm{rad}$ at $\sim 37^{\circ} \mathrm{C}$. The air-saturated solutions were contained in borosilicate glass bottles with ground-glass stoppers.

Qualitative identification of nitrate deficiency. Solutions with $\mathrm{pH}>7$ were obviously nitrate-deficient. The following test was useful for identifying nitrate-deficiency in solutions with $\mathrm{pH}<7$.

To $5-\mathrm{mL}$ sample, $100 \mu \mathrm{L}$ of $10 \% \mathrm{KF}$ was added. A pH increase to above $\mathrm{pH} 7$ indicated the solution was nitrate-deficient.

Quantitative determination of nitrate deficiency. Gadolinium content was first determined by EDTA titration. Then this equivalent amount of $\mathrm{Na}_{2} \mathrm{H}_{2}$ EDTA solution was added to a second $5-\mathrm{mL}$ sample. If the measured $\mathrm{pH}$ was greater than 7 , the solution was titrated to $\mathrm{pH} 7$ with standard $0.01 \mathrm{M} \mathrm{HCl}$; if the $\mathrm{pH}$ was less than 7 , titration was with standard $0.01 \mathrm{M} \mathrm{NaOH}$. The $\%$ nitrate deficiency was calculated as follows:

for $\mathrm{pH}>7: \frac{(2 \times \text { mmoles Gd })+(\text { mmoles HC1 })}{(3 \times \text { mmoles Gd })} \times 100$ for $\mathrm{pH}<7: \frac{(2 \times \text { mmoles } \mathrm{Gd})-(\text { mmoles } \mathrm{NaOH})}{(3 \times \text { mmoles Gd })} \times 100$ 


\section{RESULTS AND DISCUSSION}

Preparation of solutions. Nitrate-deficient solutions were produced by selective removal of nitrate from $0.001 \mathrm{M}$ gadolinium nitrate solutions by Amberlite ${ }^{\circledR}$ IRA-400( $\left(\mathrm{OH}^{-}\right)$. A variety of soluble gadolinium hydroxo complexes will be present in these solutions, depending on the degree of nitrate depletion. The action of the resin is illustrated by the reaction:

$$
\mathrm{Gd}\left(\mathrm{NO}_{3}\right)_{3}+\mathrm{nResOH} \rightarrow \mathrm{Gd}(\mathrm{OH})_{\mathrm{n}}(3-n)++(3-\mathrm{n}) \mathrm{NO}_{3}^{-}+\mathrm{nResNO}_{3}
$$

In the batch preparation method, the degree of nitrate depletion could be controlled by the amount of resin added. In the column preparation method, the composition of the effluent was less predictable.

The colum effluents had a $\mathrm{pH}>9$, but were not visibly turbid. More than $80 \%$ of the gadolinium passed through the column, presumably as soluble hydroxo complexes. The mole ratio of $\mathrm{Gd} / \mathrm{NO}_{3}$ in the effluent was several times greater than that in the influent. Both the gadolinium and nitrate that remained on the resincolumns were retained in the upper part of the column.

Properties of nitrate-deficient solutions. The $\mathrm{pH}$ of the solutions varied with the degree of nitrate depletion and with age. Fig. I shows the decrease in $\mathrm{pH}$ and the change in conductivity for a typical solution prepared by the column method and aged at room temperature. The $\mathrm{pH}$ of the initial solution was high, but decreased rapidly during the first few days; a steady 
value was reached within two to three weeks. Conductivity, determined on a separate portion of that solution, decreased rapidly for about a week, then increased, to reach a steady value of $\sim 10 \mu \mathrm{mho} / \mathrm{cm}$. The mechanism that caused the conductivity rise after several aging days was not investigated, but the conductivity increase probably reflects formation of gadolinium species of higher mobility and/or release of free nitrate as the solution and precipitate age.

The conductivity was roughly proportional to the soluble gadolinium concentration rather than to total gadolinium (Fig. 2). These conductivities were measured on aged solutions with different degrees of nitrate depletion. The solutions were prepared by the batch method from $0.001 \mathrm{M}$ gadolinium nitrate solutions in $\mathrm{H}_{2} \mathrm{O}$ and $\mathrm{D}_{2} \mathrm{O}$. They were not visibly turbid, and they contained about $0.001 \mathrm{M}$ total gadolinium.

The slope of the line in Fig. 2 provides an estimate of the average equivalent conductance of the "soluble"* gadolinium species: $\sim 122$ mho- $\mathrm{cm}^{2}$ in $\mathrm{H}_{2} \mathrm{O}$ and 102 mho- $\mathrm{cm}^{2}$ in $\mathrm{D}_{2} \mathrm{O}$. These values are close to the equivalent conductances of stoichiometric $0.001 \mathrm{M} \mathrm{Gd}\left(\mathrm{NO}_{3}\right)_{3}[8]$.

Effect of gamma radiation. Table 1 shows the effect of the gamma irradiation on nitrate-deficient solutions of different ages and degrees of nitrate depletion. Turbidity changes were slight, but turbidity generally increased with irradiation. *"Soluble" gadolinium is defined as that not filtered out by a 0.45 -micron Millipore ${ }^{\circledR}$ filter. 
Conductivity changes were variable, reflecting the age of the solution when irradiated, as illustrated in Fig. 1. The decrease in $\mathrm{pH}$ and the increase in the fraction of insoluble gadolinium in the irradiated solutions, as compared with the unirradiated solutions, was interpreted to mean that irradiation enhanced the rate of aging of the solution.

The effect of irradiation on aging behavior is illustrated in Fig. 3. The $\mathrm{pH}$ is shown as a function of time for two portions of the same solution, one portion of which was irradiated. The solution was freshly prepared before the irradiation. The $\mathrm{pH}$ of the irradiated solution decreased sharply and then continued to decrease much more rapidly than that of the unirradiated solution. This increase in the rate of aging is probably due to coagulation of the charged colloidal gadolinium species by the ionizing radiation. This phenomenon has been observed in other colloidal systems [9].

Determination of solubility product constants. The concentration of soluble gadolinium [Gd] and the measured $\mathrm{pH}$ or $\mathrm{pD}$ were used to calculate solubility product constants, $\mathrm{K}_{\mathrm{sp}}$, defined by:

$$
\mathrm{K}_{\mathrm{sp}}=[\mathrm{Gd}][\mathrm{OH}]^{3}
$$

The hydroxide concentration $[\mathrm{OH}]$ is derived from the measured $\mathrm{pH}$ (and [OD] from $\mathrm{pD}$ ) through the respective ionization constants of $\mathrm{H}_{2} \mathrm{O}$ [10] and $\mathrm{D}_{2} \mathrm{O}$ [11]. Thus, at $25^{\circ} \mathrm{C}$, the solubility product constants can be calculated from the following: 


$$
\begin{aligned}
& \text { in } \mathrm{H}_{2} \mathrm{O}: \mathrm{pK}_{\mathrm{sp}}=-\log [\mathrm{Gd}]+3(\mathrm{pH}-14.00) \\
& \text { in } \mathrm{D}_{2} \mathrm{O}, \mathrm{pK}_{\mathrm{sp}}=-\log [\mathrm{Gd}]+3(\mathrm{pD}-14.87) \\
& \text { Because of the effect of aging, an exact } \mathrm{K}_{\mathrm{sp}} \text { is difficult }
\end{aligned}
$$
to establish. As the solution ages, the colloidal particles agglomerate and become less soluble, which is reflected by a decrease in $\mathrm{pH}$ and a corresponding increase in $\mathrm{pK}_{\mathrm{sp}}$. For freshly precipitated $\mathrm{Gd}(\mathrm{OH})_{3}$, the $\mathrm{pK}_{\mathrm{sp}}$ is 21.7 [12]. For $\mathrm{Gd}(\mathrm{OH})_{3}$ aged 200 days, the $\mathrm{pK}_{\mathrm{sp}}$ is 26.88 [13].

Table 2 shows a set of solutions in $\mathrm{H}_{2} \mathrm{O}$ in which the average $\mathrm{pK}_{\mathrm{sp}}$ was 25.5 , after 7 days of aging. Three solutions that were irradiated (and hence more aged) produced an average $\mathrm{pK}_{\mathrm{sp}}$ of 26.8 , in essential agreement with the published value for $\mathrm{Gd}(\mathrm{OH})_{3}$ that was aged 200 days.

Table 2 also shows a set of 7-day-old solutions in $\mathrm{D}_{2} \mathrm{O}$ had an average $\mathrm{pK}_{\mathrm{sp}}$ of 26.6. Extrapolation from the $\mathrm{H}_{2} \mathrm{O}$ data indicates the $\mathrm{pK}_{\mathrm{sp}}$ in $\mathrm{D}_{2} \mathrm{O}$ after prolonged aging would be $\sim 27.9$.

Analysis of nitrate-deficient solutions. The solutions are regarded as containing the hypothetical gadolinium compound $\mathrm{Gd}(\mathrm{OH})_{n}\left(\mathrm{NO}_{3}\right)_{3-n}$. The degree of nitrate deficiency is determined from the amount of hydroxide released when the gadolinium is complexed. Hydroxide is qualitatively detected by $\mathrm{pH}$ measurement or quantitatively determined by acid titration.

In the qualitative procedure, excess fluoride is added, which complexes gadolinium as the fluoride and releases hydroxyl ions:

$$
\begin{gathered}
\mathrm{Gd}(\mathrm{OH})_{n}\left(\mathrm{NO}_{3}\right)_{3-\mathrm{n}}+\operatorname{excess} \mathrm{F}^{-} \rightarrow \mathrm{GdF}_{3}+\mathrm{KNO}_{3}+\mathrm{n} \mathrm{OH}^{-} \\
-8-
\end{gathered}
$$


If the pH increases above the neutral point, nitrate deficiency is indicated. In theory, for quantitative determination, the $\mathrm{OH}^{-}$released after fluoride addition can be titrated with standard acid. In practice, the end point is diffuse because of the buffering action of the fluoride, and more satisfactory results are obtained with the EDTA procedure described below.

For quantitative determination, addition of an equivalent amount of $\mathrm{Na}_{2} \mathrm{H}_{2}$ EDTA for gadolinium complexation releases two hydrogen ions from the EDTA as well as the $\mathrm{OH}^{-}$from the gadolinium species:

$$
\begin{aligned}
& \mathrm{Gd}(\mathrm{OH})_{n}\left(\mathrm{NO}_{3}\right)_{3-\mathrm{n}}+\mathrm{Na}_{2} \mathrm{H}_{2} \mathrm{EDTA} \rightarrow \\
& \mathrm{GdEDTA}^{-}+(\mathrm{n}-3) \mathrm{NO}_{3}^{-}+2 \mathrm{Na}^{+}+\mathrm{nOH}^{-}+2 \mathrm{H}^{+}
\end{aligned}
$$

The net $\left[\mathrm{H}^{+}\right]$or $\left[\mathrm{OH}^{-}\right]$is determined by titration with standard base or acid.

Table 3 shows the results when these procedures were used to analyze a set of gadolinium nitrate solutions with different degrees of nitrate depletion. The first three solutions were untreated gadolinium nitrate.

The qualitative test identified nitrate deficiency in these solutions with $\mathrm{pH}<7$, by the increase in $\mathrm{pH}$ above the neutra1 point of 7 . The quantitative results indicate that the untreated $\mathrm{Gd}\left(\mathrm{NO}_{3}\right)_{3}$ solutions may have been slightly nitrate-rich. Nitrate deficiency values follow the same sequence as the $\mathrm{pH}$ change of the qualitative test for all the samples. 
The last column provides a comparison with nitrate deficiencies determined from independent nitrate determinations by ion-selective electrode, ion chromatography, and ion exchange procedures. The good agreement confirms the reliability of the determination by EDTA.

\section{REFERENCES}

1. L. A. Heinrich, Nuclear Safety, 7, 175, Winter 1965-66.

2. C. F. Baes, Jr., and R. E. Mesmer, The Hydrolysis of Cations, Chapter 7, Wiley, New York (1976).

3. L. Meites, Ed., Handbook of Analytical Chemistry, p. 3-187, McGraw-Hi11, New York (1963):

4. J. C. MacDonald, Amer. Lab., 11, 45 (1979).

5. Orion Research Incorporated, Newsletter/Specific Ion Electrode Technology, II, Nos. 7 and 8, 35 (1970).

6. R. Gary, R. G. Bates, and R. A. Robinson, J. Phys. Chem., $69,2750(1965)$.

7. R. G. Bates, Anal. Chem., 40, 28A (1968).

8. E. W. Baumann, J. Inorg. Nuc1. Chem., in press.

9. A. 0. Allen, The Radiation Chemistry of Water and Aqueous Solutions, p 113. Van Nostrand, Princeton, NJ (1961).

10. R. A. Robinson and R. H. Stokes, Electrolyte Solutions, p 544, Butterworths, London (1970).

11. A. K. Covington, R. A. Robinson, and R. G. Bates, J. Phys. Chem., 70, 3820 (1966). 
12. T. Moeller and H. E. Kremers, J. Phys. Chem., 48, 395 (1944) .

13. N. V. Aksel'rud, Zh. neorg. Khim., 8, 11 (1963). 
Table 1. Irradiation of Nitrate-Deficient Solutions

\begin{tabular}{|c|c|c|c|c|c|c|c|c|}
\hline Solution & $\begin{array}{l}\text { Mode of } \\
\text { Preparation }\end{array}$ & $\begin{array}{l}\text { Age when } \\
\text { Irradiated }\end{array}$ & $\begin{array}{l}\text { Turbidity, } \\
\text { NTU }^{\mathrm{a}}\end{array}$ & $\begin{array}{l}\text { Conductivity } \\
\text { umho/cm }\end{array}$ & $\mathrm{pH}$ & $\begin{array}{l}\text { Gadolin } \\
\text { Total, } \\
10^{-4} \mathrm{M}\end{array}$ & $\begin{array}{l}\text { un } \\
\text { Fraction } \\
\text { "Insoluble"b }\end{array}$ & $\begin{array}{l}\text { Nitrate, } \\
10^{-4} \mathrm{M}\end{array}$ \\
\hline${ }_{1}^{1} d$ & column & 2 days & $\begin{array}{l}2.5 \\
9.7\end{array}$ & $\begin{array}{l}10.5 \\
39.4\end{array}$ & $\begin{array}{l}9.17 \\
6.55\end{array}$ & $\begin{array}{l}8.9 \\
8.9\end{array}$ & $\begin{array}{l}0.18 \\
0.86\end{array}$ & $c$ \\
\hline${ }_{2}^{2} d$ & column & 7 days & $\begin{array}{l}14.5 \\
15.0\end{array}$ & $\begin{array}{l}4.7 \\
9.5\end{array}$ & $\begin{array}{l}9.22 \\
6.70\end{array}$ & $\begin{array}{l}7.0 \\
7.0\end{array}$ & $\begin{array}{l}0.75 \\
0.95\end{array}$ & $c^{4.7}$ \\
\hline${ }_{3}^{3} d$ & batch & 1 day & $\begin{array}{l}1.9 \\
1.9\end{array}$ & $\begin{array}{l}147 \\
156\end{array}$ & $\begin{array}{l}7.41 \\
6.23\end{array}$ & $\begin{array}{l}6.2 \\
6.2\end{array}$ & $\begin{array}{l}0.13 \\
0.25\end{array}$ & $c^{13}$ \\
\hline${ }_{4}^{4} d$ & column & 6 hours & $\begin{array}{l}0.67 \\
0.95\end{array}$ & $\begin{array}{c}14.7^{\circ} \\
5.8\end{array}$ & $\begin{array}{l}9.6 \\
\text { B.6 }\end{array}$ & $\begin{array}{l}8.6 \\
8.6\end{array}$ & $\begin{array}{l}0.03 \\
0.25\end{array}$ & $c^{4.4}$ \\
\hline
\end{tabular}

\footnotetext{
${ }^{\text {a }}$ TU = Nephelometric Turbidity Units

b Rewoved by filtration through 0.45 -micron filter

$c$ Not deternined

d Irradiated to gamma dose of 7 megarads
}

Table 2. Solubility product constants of $\mathrm{Gd}(\mathrm{OH})_{3}$ and $\mathrm{Gd}(\mathrm{OD})_{3}$ at $25^{\circ} \mathrm{C}$

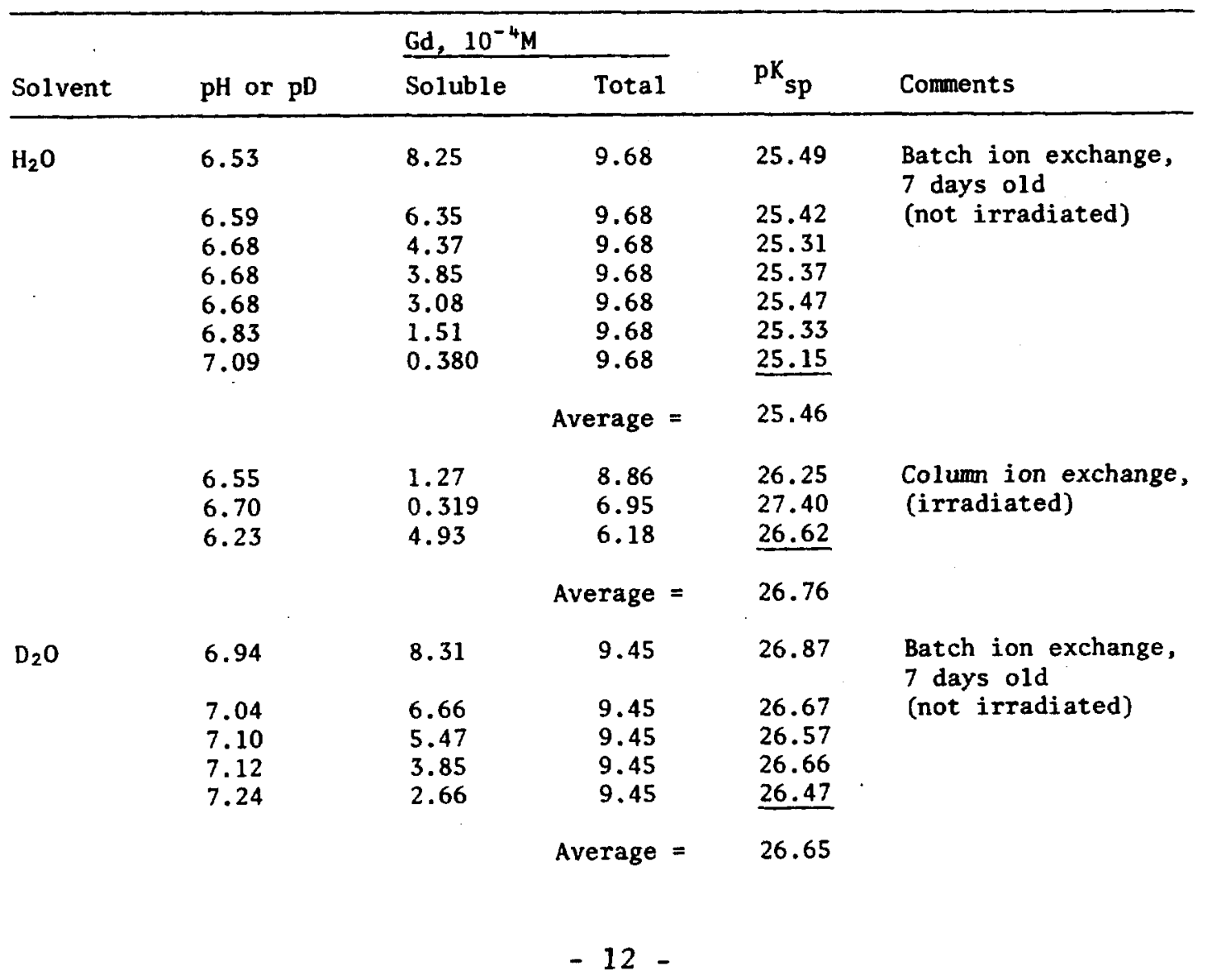


Table 3. Nitrate Deficiency

\begin{tabular}{|c|c|c|c|c|}
\hline Solution & $\begin{array}{l}\text { Total } \mathrm{Gd}^{3+} \\
10^{-4} \mathrm{M}\end{array}$ & $\begin{array}{l}\text { Qualitative } \\
\text { Procedure } \mathrm{A}, \\
\text { pH change }\end{array}$ & $\begin{array}{l}\text { Ditrate } \\
\text { By } \\
\text { EDTA } \\
\text { Procedure }\end{array}$ & 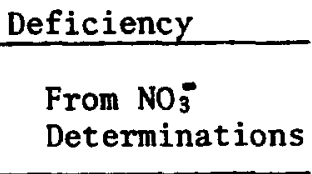 \\
\hline \multirow[t]{3}{*}{$\mathrm{Gd}\left(\mathrm{NO}_{3}\right)_{3}$} & 9.50 & 5.6 to 7.0 & -3 & -- \\
\hline & 9.60 & 5.6 to 7.0 & -5 & -- \\
\hline & 9.83 & 5.6 to 7.0 & -4 & $-2^{a}$ \\
\hline \multirow[t]{4}{*}{$\begin{array}{l}\text { Nitrate } \\
\text { Deficient } \\
\text { Solutions }\end{array}$} & 7.56 & $\begin{array}{l}6.1 \text { to } 8.7 \\
6.2 \text { to } 9.3\end{array}$ & 9.5 & $\begin{array}{l}16^{\mathrm{a}} \\
32^{\mathrm{b}, \mathrm{c}}\end{array}$ \\
\hline & 6.93 & 7.3 to 10.3 & 76 & -- \\
\hline & 6.80 & 8.8 to 10.5 & 82 & -- \\
\hline & 8.09 & 8.5 to 10.6 & 87 & $86^{c}$ \\
\hline \multicolumn{5}{|c|}{ a Ion selective electrode } \\
\hline \multicolumn{5}{|c|}{ b Ion chromatograph } \\
\hline
\end{tabular}




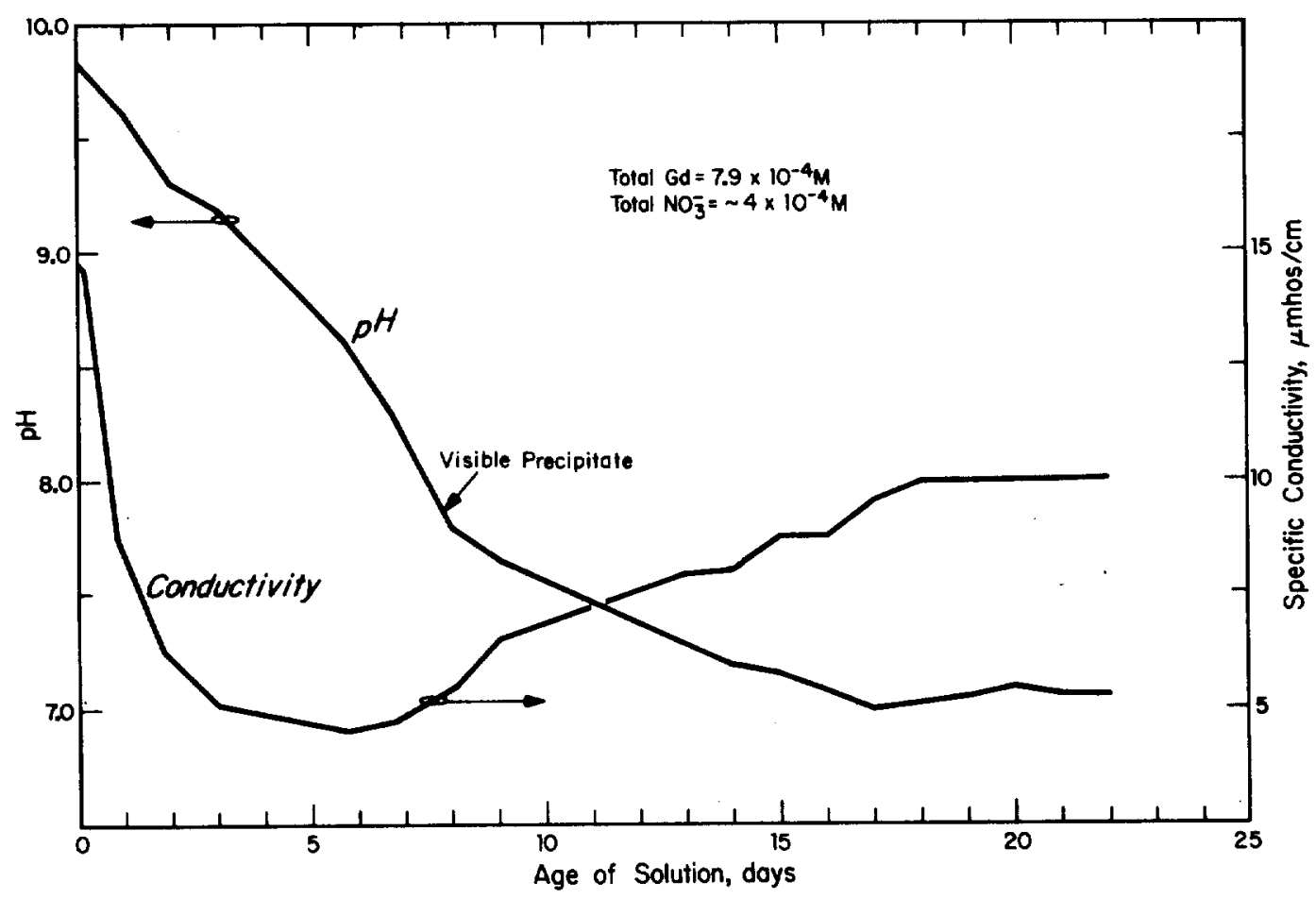

Fig. 1. $\mathrm{pH}$ and conductivity during aging of nitrate-deficient gadolinium nitrate solution at $25^{\circ} \mathrm{C}$ 


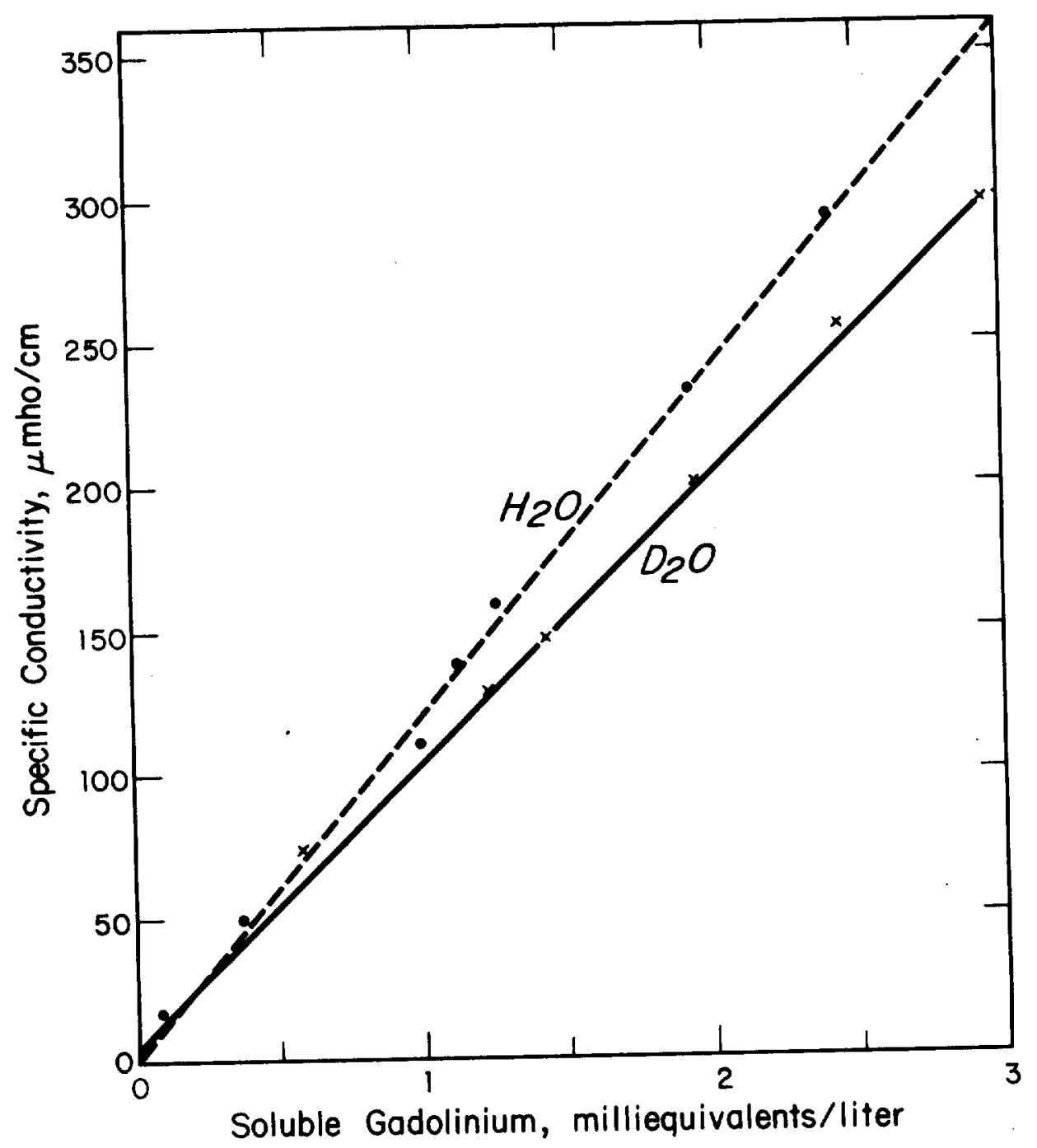

Fig. 2. Conductivity and soluble gadolinium in aged nitrate-deficient gadol inium nitrate solutions in $\mathrm{H}_{2} \mathrm{O}$ and $\mathrm{D}_{2} \mathrm{O}$ at $25^{\circ} \mathrm{C}$ 


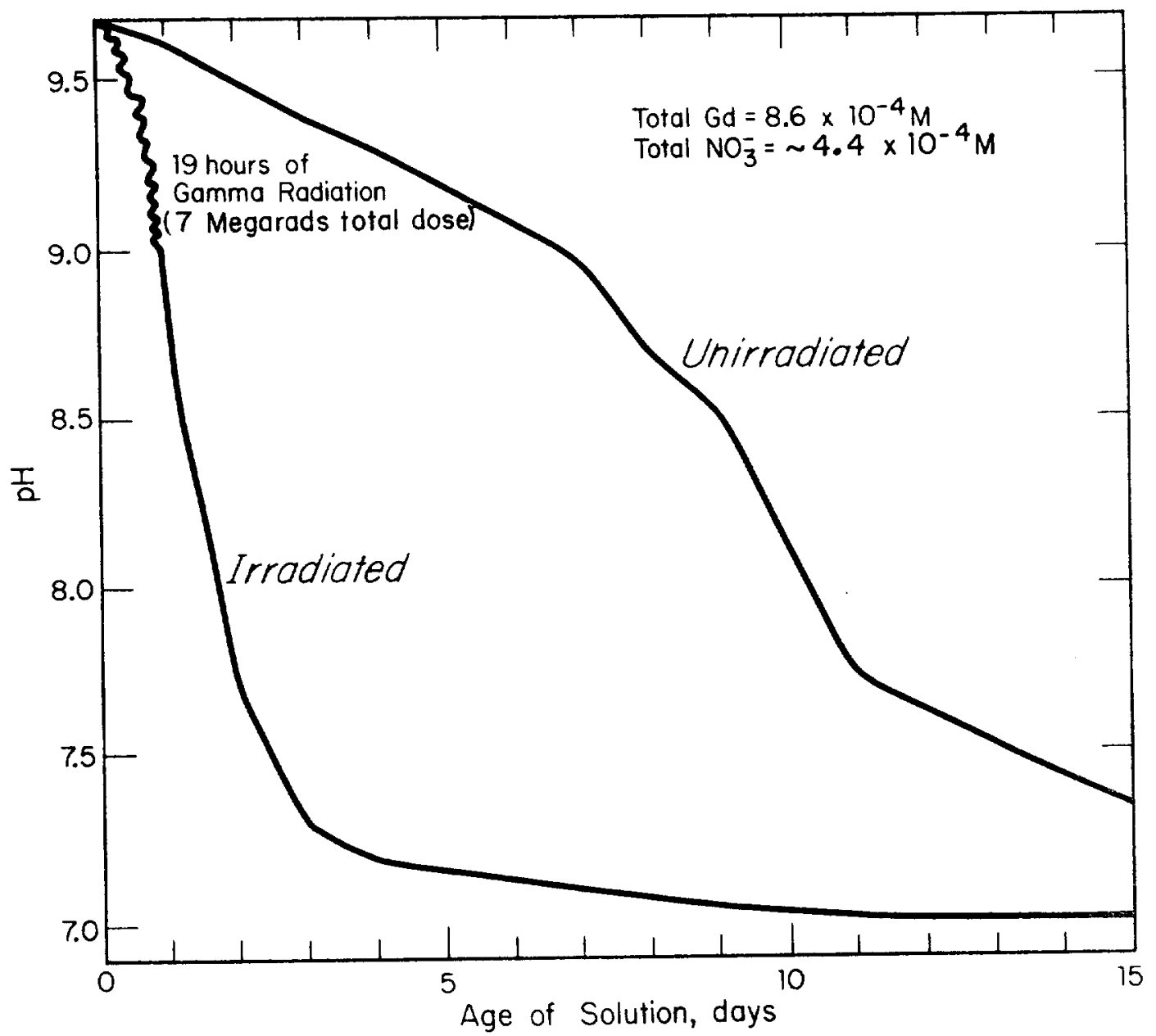

Fig. 3. Effect of gamma irradiation on aging of nitrate-deficient gadolinium nitrate solution at $25^{\circ} \mathrm{C}$ 